\title{
Transthyretin (ATTR) amyloidosis nephropathy: lessons from a TTR stabilizer molecule
}

\section{Ana Rocha, Ana Silva, Márcio Cardoso, Idalina Beirão, Cristina Alves, Paulo Teles, Teresa Coelho \& Luísa Lobato}

To cite this article: Ana Rocha, Ana Silva, Márcio Cardoso, Idalina Beirão, Cristina Alves, Paulo Teles, Teresa Coelho \& Luísa Lobato (2017) Transthyretin (ATTR) amyloidosis nephropathy: lessons from a TTR stabilizer molecule, Amyloid, 24:sup1, 81-82, DOI: 10.1080/13506129.2016.1277697

To link to this article: https://doi.org/10.1080/13506129.2016.1277697

\section{册 Published online: 22 Apr 2017.}

Submit your article to this journal

Џlll Article views: 56

Q View related articles $\sqsubset$

View Crossmark data $\asymp$ 


\title{
Transthyretin (ATTR) amyloidosis nephropathy: lessons from a TTR stabilizer molecule
}

\author{
Ana Rocha ${ }^{1,2}$, Ana Silva ${ }^{1,3}$, Márcio Cardoso ${ }^{1,4}$, Idalina Beirão ${ }^{1,5}$, Cristina Alves ${ }^{1}$, Paulo Teles ${ }^{6}$, Teresa Coelho ${ }^{1,4}$, and \\ Luísa Lobato ${ }^{1,2,5}$ \\ ${ }^{1}$ Unidade Corino de Andrade, Porto, Portugal, ${ }^{2}$ Unit for Multidisciplinary Research in Biomedicine (UMIB), Instituto de Ciências Biomédicas Abel \\ Salazar (ICBAS), Porto University, Porto, Portugal, ${ }^{3}$ Department of Neurology, Centro Hospitalar do Porto, Porto, Portugal, ${ }^{4}$ Department of \\ Neurophisiology, Centro Hospitalar do Porto, Porto, Portugal, ${ }^{5}$ Department of Nephrology, Centro Hospitalar do Porto, Porto, Portugal, and \\ ${ }^{6}$ School of Economics and LIAAD-INESC Porto LA, Porto University, Porto, Portugal
}

\section{Background}

Tafamidis delayed neuropathic progression in patients with transthyretin amyloidosis [1], but long-term effectiveness in multisystem commitment is unclear. In renal involvement, albuminuria represents the first stage of clinical nephropathy with progression to nephrotic proteinuria and end-stage renal disease as natural course of the disease. The distribution of amyloid deposits is according to the grade of proteinuria; glomerular and vascular involvement predominates in proteinuric patients [2]. No effective treatment exists for renal disease. The survival on dialysis is poor, and liver and kidney transplantations are reserved for a strict number of patients. Clinical trials of approved anti-amyloid drugs were never applied to patients with severe nephropathy then, effectiveness in kidney disease is unclear. This study investigates the long-term effects of tafamidis on patients who had kidney transthyretin amyloidosis in terms of kidney function and proteinuria.

\section{Materials and methods}

An open-label, nonrandomized, prospective evaluation was conducted. Twelve patients (11 female, 1 male), with neuropathy stage I and estimated glomerular filtration rate (eGFR) $\geq 60 \mathrm{~mL} / \mathrm{min}$, were treated with tafamidis, receiving $20 \mathrm{mg}$ QD. Kidney function was evaluated by measuring creatinine and cystatin C. Proteinuria and urine creatinine were measured in a spot urine collection. Determinations and patient clinical evaluation were made at baseline and at all subsequent visits every 6 months. We also divided the patients into two groups on the basis of final proteinuria: 5 patients with proteinuria $<30 \mathrm{mg}$ and 4 patients with proteinuria $>30 \mathrm{mg}$, and compared them. The unpaired Student's $t$-test

Address for correspondence: Ana Rocha, Unidade Corino de Andrade, Centro Hospitalar do Porto - R. D. Manuel II, 4050-345 Porto, Portugal. E-mail: acrisbraga@gmail.com and the nonparametric Wilcoxon-Mann-Whitney test were used to determine the significance of differences.

\section{Results}

Nine patients completed 36 months of therapy, 2 patients completed 30 months and 1 patient completed 18 months. The mean age was $51 \pm 11$ years at the time tafamidis was begun and the mean duration of neuropathy was $5 \pm 4$ years. Two patients had kidney biopsies, all had transthyretin amyloidosis. Only one patient was under an angiotensin-II inhibitor During the study period, kidney function remained stable with sustained reductions in proteinuria (Table 1). GFR calculated using CKD-EPI, MDRD and Cockcroft-Gault formulas was, respectively, at enrollment and at the end of follow-up of 98.8 and $98.4,95.8$ and $95.3,83.1$ and $80.5 \mathrm{ml} / \mathrm{min}$. The patients with proteinuria $>30 \mathrm{mg}$ had higher significant values of creatinine and cystatin $\mathrm{C}$ across all assessments (Table 2).

\section{Discussion and conclusions}

Over the course of 36 months of tafamidis, there was no change in kidney function with sustained reduction in proteinuria. This suggests that tafamidis may slow or halt kidney disease demonstrating the feasibility of this therapy in patients with kidney transthyretin amyloidosis. It should be used before extensive kidney damage occurs as anticipated by the higher reduction of proteinuria in patients with lower levels of creatinine and cystatin $\mathrm{C}$. This is a new facet of the

Table 1. Proteinuria and urine protein/creatinine ratio.

\begin{tabular}{|c|c|c|c|c|c|c|}
\hline & Mean & $\begin{array}{l}\text { Standard } \\
\text { deviation }\end{array}$ & $t$ & $p$ Values & $W$ & $p$ Values \\
\hline \multicolumn{3}{|c|}{ Proteinuria (mg) } & \multirow[t]{3}{*}{5.3} & \multirow[t]{3}{*}{0.0004} & \multirow[t]{3}{*}{54} & \multirow[t]{3}{*}{0.002} \\
\hline Baseline & 1099.1 & 607.9 & & & & \\
\hline Month 36 & 64.5 & 94.9 & & & & \\
\hline \multicolumn{3}{|c|}{ Urine protein/creatinine ratio } & \multirow[t]{3}{*}{3.9} & \multirow[t]{3}{*}{0.002} & \multirow[t]{3}{*}{45} & \multirow[t]{3}{*}{0.002} \\
\hline Baseline & 0.93 & 0.56 & & & & \\
\hline Month 36 & 0.22 & 0.14 & & & & \\
\hline
\end{tabular}


Table 2. Comparison between patients with proteinuria $<30 \mathrm{mg}$ (group I) and $>30 \mathrm{mg}$ (group II).

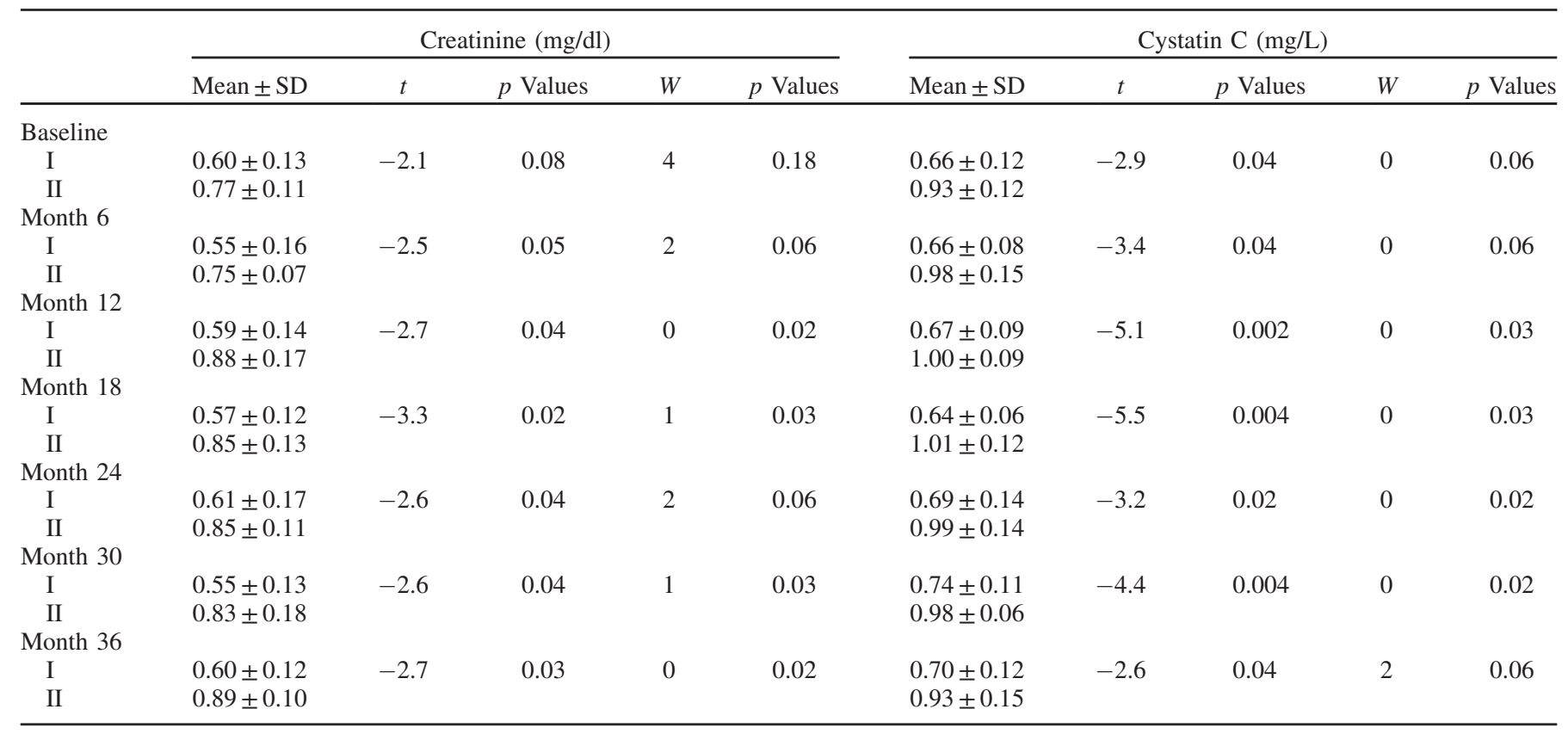

drug, since previous clinical trials did not include nephropathy as an end-point of treatment.

\section{Declaration of interest}

Dr Coelho has served on the speakers bureau of Pfizer Inc. The other authors report no conflicts of interest.

\section{References}

1. Coelho T, Maia LF, da Silva AM, Waddington Cruz M, PlantéBordeneuve V, Lozeron P, Suhr OB, et al. Long-term effects of tafamidis for the treatment of transthyretin familial amyloid polyneuropathy. J Neurol 2013;260:2802-14.

2. Lobato L, Rocha A. Transthyretin amyloidosis and the kidney. Clin J Am Soc Neurol 2012;7:1337-46. 